\title{
DEFORMATION OF UNCONSOLIDATED BEDS IN NOVA SCOTIA AND SOUTHERN ONTARIO ${ }^{1}$
}

\author{
BY E. M. KINDLE
}

(Read before the Society December 29,1916 )

\section{CONTENTS}

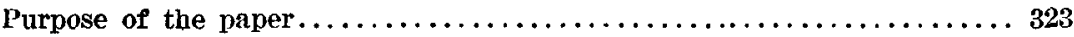

Deposition and erosion in the Bay of Fundy................... 323

Sediments of the Avon and other rivers..................... 326

Artiflial deformation of soft beds......................... 327

Explanation of the disturbed beds of Avon River................ 332

The cliffs of Port Rowan, Ontario......................... 332
\end{abstract}

\section{Purpose of the Paper}

Deformation in which a few feet or a few inches of a section have been crumpled and contorted without disturbing the adjacent strata attracted the notice of geologists as early as 1846, when Emmons ${ }^{2}$ described the disturbed clays at Albany, New York. Although a number of examples of this phenomenon have been described and various explanations of it offered, the subject appears to be still open to experimental investigation.

It is proposed in this paper to cite two examples of contorted beds which have come under my notice and to describe some experiments which illustrate the principles involved in certain classes of contorted beds.

\section{Deposition and Erosion in the Bay of Fundy}

Deposition and erosion both proceed with great rapidity on the mudflats about the estuaries of the Bay of Fundy because of the strong tidal currents and the great volume of suspended sediment in the waters. A considerable part of the load of fine silt is dropped at each flood tide,

t Manuscript received by the Secretary of the Society January 29, 1917.

Published with the permission of the Iirector of the Geologlcal Survey of Canada.

${ }^{2}$ Remarks on the drift period. Am. Quart. Jour. Agric. and Sel., vol. 6, 1847, p. 218. 
when the current is at the minimum strength, which is mostly picked up again by the strong ebb currents. The constant shifting of the equilibrium between the two agencies, sedimentation and scour, results in areas in which deposition is dominant and others where crosion is the ruling factor. In the latter areas some interesting features connected

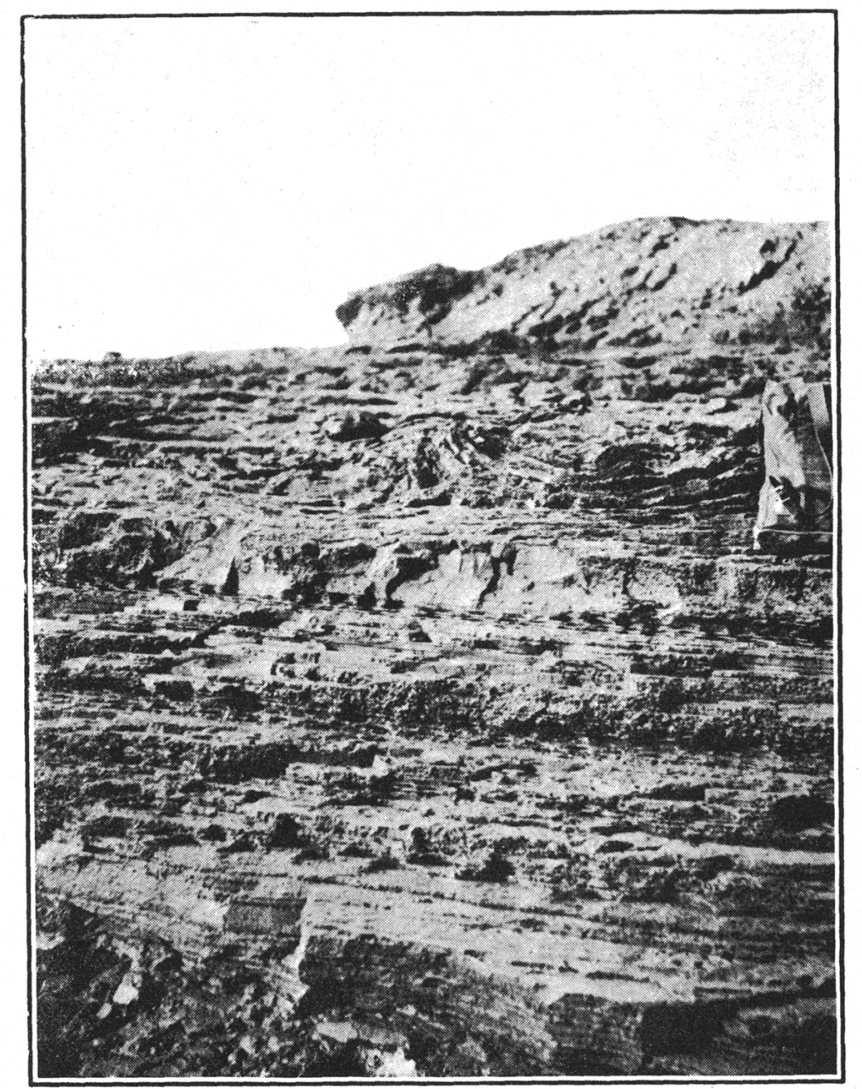

Figura 1. Sertion with disturbed Beds between horizontal luminuted silts, Avon River, Nova Scotia

with sedimentation are sometimes well displayed. The individual laminx generally vary between one-eighth and one-quarter of an inch in thickness. Some of the exposures exhibit horizontal beds which have been cut into hollows, which later were filled by sediments in which the laminæ partake of the slope of the hollows which they fill and are thus deflected from a horizontal attitude through their subaqueous disconformable relations. 
Irregularity of bedding of a different character which is subsequent in origin to deposition occurs at other localities. The point on the lower side of the junction of the Avon and Saint Croix rivers shows horizontal, contorted, and highly inclined beds, which occur in close relationship to each other (figure 1). The disturbed and contorted beds are here interpolated between horizontal beds (figure 2). Inspection of figure 2 will show a section of finely laminated horizontal silts, which, for a thickness of one foot or more near the middle, have been distorted into a highly convoluted zone. This occurrence of contorted strata in the midst of a series of undisturbed horizontal beds appears to duplicate in unconsoli-

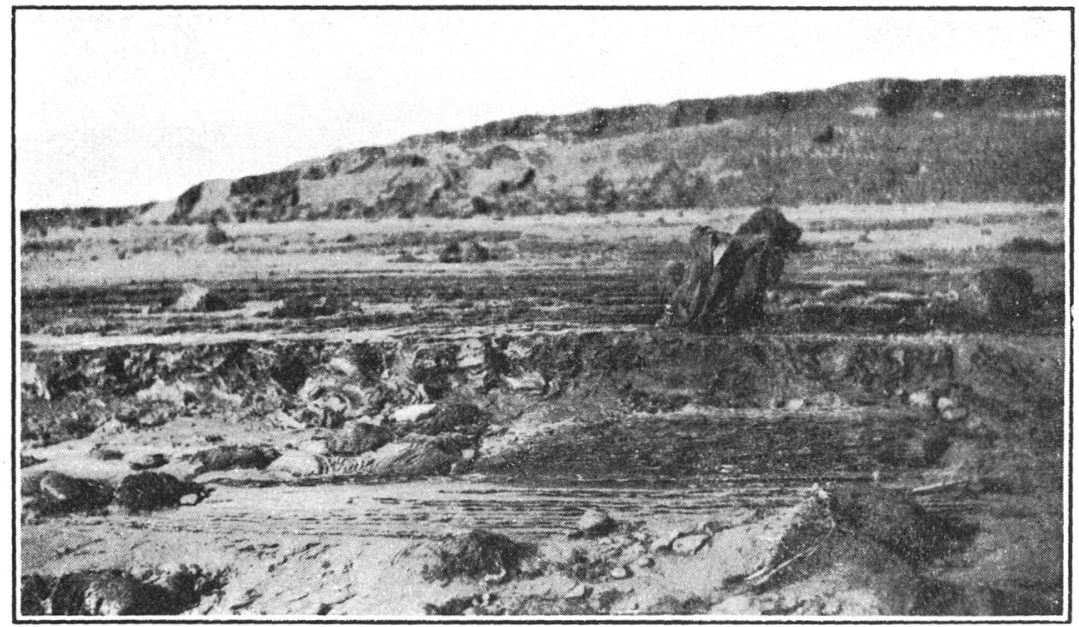

Huare 2.-Contortel strata betucen horizontal thinly laninatel clays, Avon River. Nova Scotia

dated sediments certain ases of disturbed bedding between horizontal beds which have been reported in consolidated rocks in the Gaspe l'eninsula ${ }^{3}$ and in New York. ${ }^{4}$ The recent origin of these deformed strata on the Aron River and the present operation in their immerliate vicinity of the agencies and conditions under which they must have been produced make the problem of the method of their development much simpler than

${ }^{3}$ W. E. Logan : Geology of Canada, 1863, p. 392, fig. 425.

${ }^{4}$ E. M. Kindle: Note on some concretions in the Chemung of southern New York. Am. Geol., vol. xxxiii, 1904, pp. 360-363.

W. J. Miller: Geology of the Remsen quadrangle. Bull. N. Y. State Museum, no. 1:3(; 1909, pp. 29-33.

Felix F. Irahn: Untermeerische Gleitung bei 'I'renton Falls (Nord Amerika) und ihr

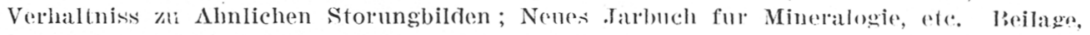
Bathe :3(; 1af, i-iii, 191:, p). 1-41. 
in the case of the Paleozoic rocks cited above. Its solution should be instructive in explaining such structures in older rocks and merits consideration.

\section{Sediments of the Avon and other Rivers}

The great bulk of the sediments handled by the estuarine currents of the Avon and other similar Nova Scotia rivers consists of fine silt and sand. Although roughly divisible into these two groups, silt and sand,

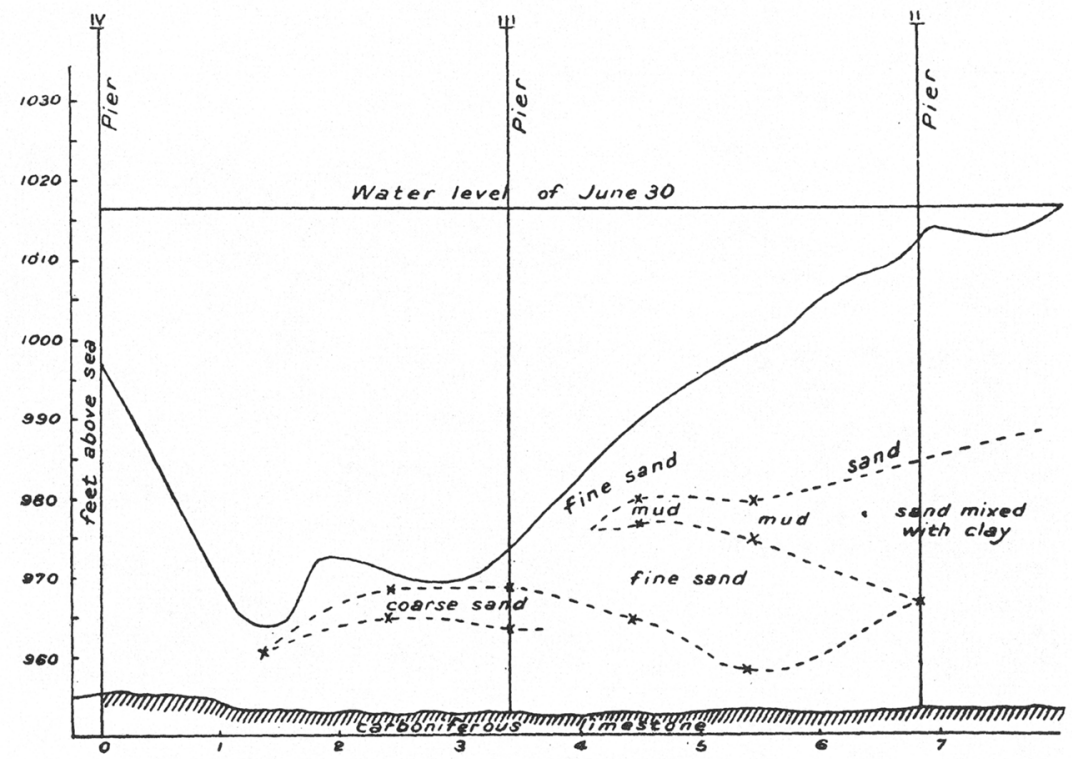

Figure 3.-Bottom Section and Profile of Missouri River at Blair, Nebraska

Showing potential conditions for horizontal mud-flow. After Todd, Bulletin number 158, U. S. Geological Survey

the estuarine sediments deposited by the currents furnish a considerable variety of muds alone. This variety, as regards consistency or coherence, which depend on water content and fineness of material, can be easily demonstrated by a short walk across any Bay of Fundy mud-flat. On parts of the flats the pedestrian will sink not deeper than his shoe tops; in others he will go in to the knees or hips, and a very moderate journey will disclose still softer mud. It is evident that belts of the very soft mud may be covered by areas of more coherent silt, and that sand deposits several feet in thickness and very heavy may be laid down over some of these very mobile sediments. If a heavy bed of sand were deposited over 
a portion of an area in which very soft beds were interpolated between more coherent strata, the more mobile beds would be likely to squeeze outward away from the sand pressure toward an unsupported edge, if one were developed by stream or wave cutting. This might occur without disturbing firmer beds above and below through the more yielding character of the soft beds.

Figure 3, which is based on a section of the deposits of the Missouri River at Blair, Nebraska, shows an arrangement of mud and sand beds which will aid in understanding the mechanical conditions under which these soft muds might be sealed between beds of sand which might hold for an indefinite period the potential power of deforming them. A small amount of bottom cutting by the river would expose the mud-beds on the right side of the section and cause them to be squeezed laterally into the river by the heary sand load above them. Such horizontal movement of the material of the soft mud-beds would inevitably produce deformation of the laminæ consequent on flowage of the beds behind them.

\section{Artificial Deformation of soft Beds}

The behavior of soft beds overlain by unequally distributed firmer and heavier beds, as observed in an experimental tank, is instructive in this connection. Marked deformation of the soft beds was thus induced by differential weighting of the firmer upper beds in a small tank. Two beds of clay, each about three-fourths of an inch thick, were deposited over the bottom of the tank by introducing the clay into the partially water-filled tank by means of a tube connected with another vessel used as a reservoir for the thoroughly mixed clay and water. Two thin layers composed respectively of powdered charcoal and plaster of paris, which was much more resistant than the clay beds, were laid on top of the first bed of clay. These show in figure 4 as white and black bands in the lower half of the section. On the level surface of the upper clay bed a delta was formed at one end of the tank by running into it a small stream of sand-bearing water. This delta, as it was formed, sank into and nearly through the upper clay bed, pressing it laterally and considerably thickening it near the sides of the delta. A second delta was made of fine sand at the opposite end of the tank. The bottom-set beds of this delta spread over the entire surface of the clay and of the other sand delta, which had covered but a small part of the clay. The two fan-shaped deltas thus developed covered the middle and sides of the clay bed with a layer of sand one-eighth to one-half of an inch thick, while a small area of the clay at each end of the tank supported a sand deposit one to two inches 
thick. The sand of these delta deposits, where it is in contact with the side of the tank, shows as a black band above the clay in figures 4 and 5 . The inequality of the load of sediment thus placed on the soft clay bed resulted in the unequally weighted clay breaking through the weakest point in the sand-bed covering it and forming a small clay dome or plug extending through the sand, as seen in the photograph, figure 4, directly muler the arrow. 'This occurred at the completion of the second delta. I'ter this photograph was taken the sand load on the clay was considerably increased to a nearly uniform depth over the clay. By means of

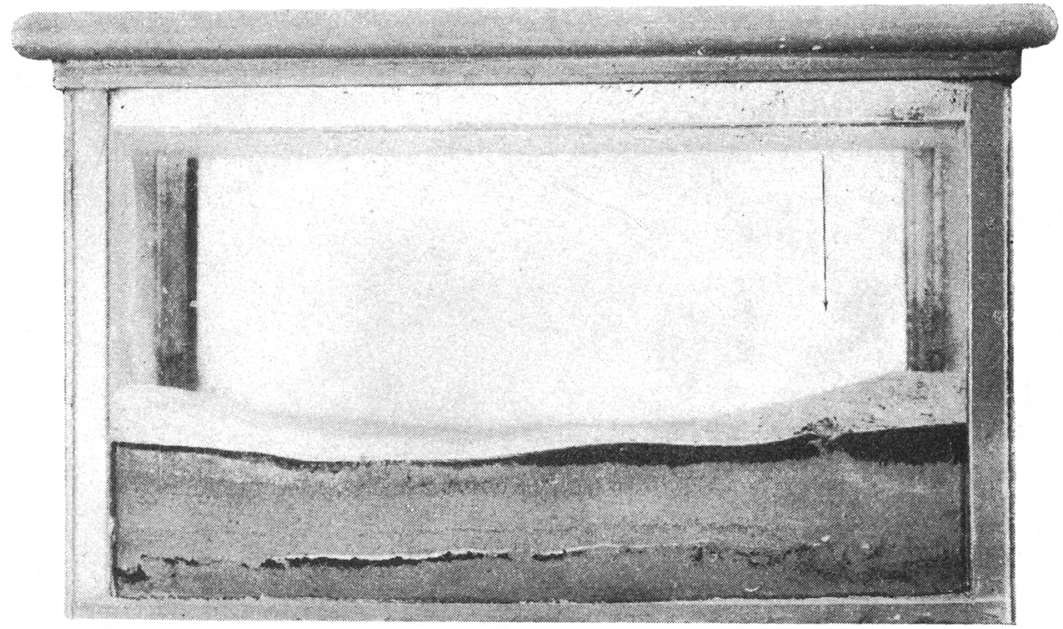

Figure 4.-Stratified Clays deposited from Water in experimental Tank

Showing "mud lump" and deformation produced by differential weighting of the clay beds with sand. The surfaces of each of the four strata below the sand were perfectly horizontal before the introduction of the sand. Note the great disturbance of the charcoal band in lower half of section and the clay plug pushed through the sand below the arrow.

current scour the sand was then somewhat reduced in thickness at one point, a small tube being used to introduce a stream of water for this purpose. Additional pressure was then placed on the sand by means of a bag of shot. This resulted in the clay slowly rising at the point where the sand load had been reduced on the side of the tank by scour (figure $5)$. The mass squeezed out through the sand assumed the shape on the upper surface of a steep-sided half dome, the contact with the face of the tank preventing the formation of a complete dome. The plug of clay continued to rise till it was slightly above the surface of the water in the tank. Examination of the photographs shows that marked disturbance 
of the charcoal band occurred in the first stage of the experiment. Later stages show coincident development in different parts of the section of doming and upthrust faulting accompanied by extensive flowage of the subsurface strata.

'This experiment duplicates, it is believed, on a small scale the phenomena of the mud lumps which rise in the delta of the Mississippi River a few feet above water level. A river delta affords a particularly favorable field for such phenomena because of the constant interplay of: marine and river eurrents and the resulting continuous shifting of the

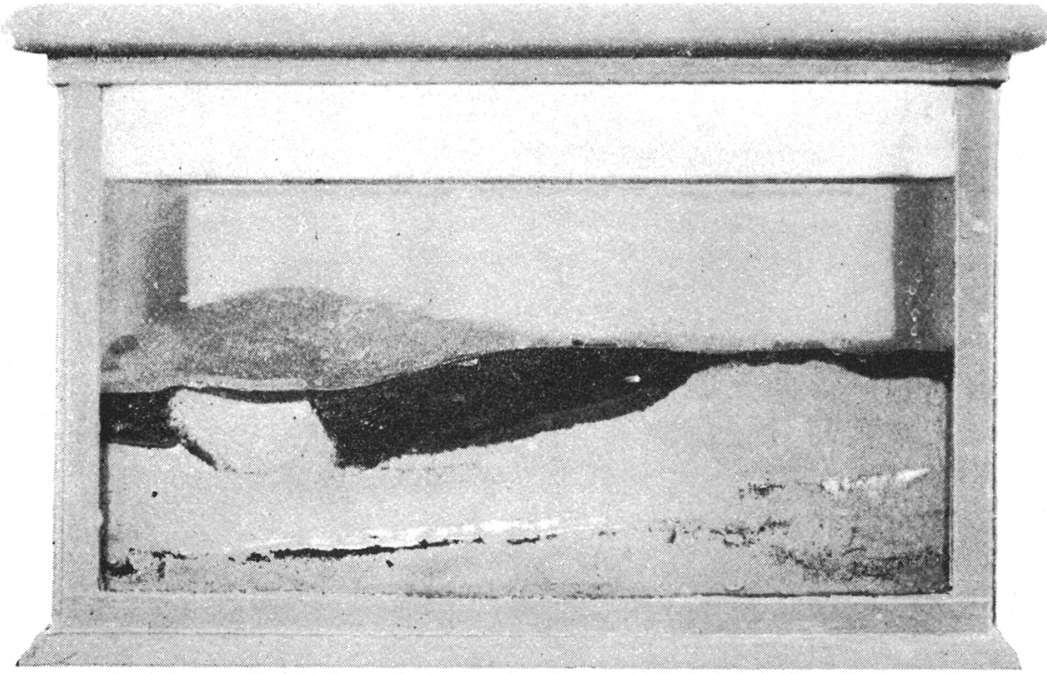

FIgURE 5.-Another View of the water-laid Beds shown in Figure 4

This result is obtained after adding sand and shot to the surface load and subjecting the sand cover in the left third of the section to current scour. The thinning of the sand cover, combined with the increased load, developed the upthrust clay plug seen on the left side of the figure.

areal relations of heavy, coarse sediment and those of lighter and more mobile character. While the mud lumps of the Mississippi appear to be unique in rising above the surface of the water, probably through being composed of material sufficiently tenacious to withstand current and wave action for some time, similar phenomena doubtless occur in many other deltas which do not become apparent through failure of the upsqueezed masses to reach the surface of the water. These experiments

${ }^{5}$ G. D. Harris: Geol. Sur. of Touisiana, Rept. for 1899, pp. 119-121 ; Rept. for 1902, [1p. 38-39.

E. W. Shaw: U. S. Geol. Surv. Prof. Paper no. 85B, 1913, pp. 11-27. 
show clearly the tendency of soft beds to move in the direction of least resistance, with a minimum amount of disturbance of firmer superposed beds under certain conditions of loading. In the illustrations, numbers 4 and 5, this direction was mainly upward, and its relationship to the phenomena presented by the contorted Nova Scotia beds is not perhaps at first sight evident, since the latter represent horizontal movement of strata. Vertical extrusion, however, of soft beds through breaks in superposed beds may directly induce horizontal flowage of the soft beds toward the extruded material. The irregular or uneven character which such

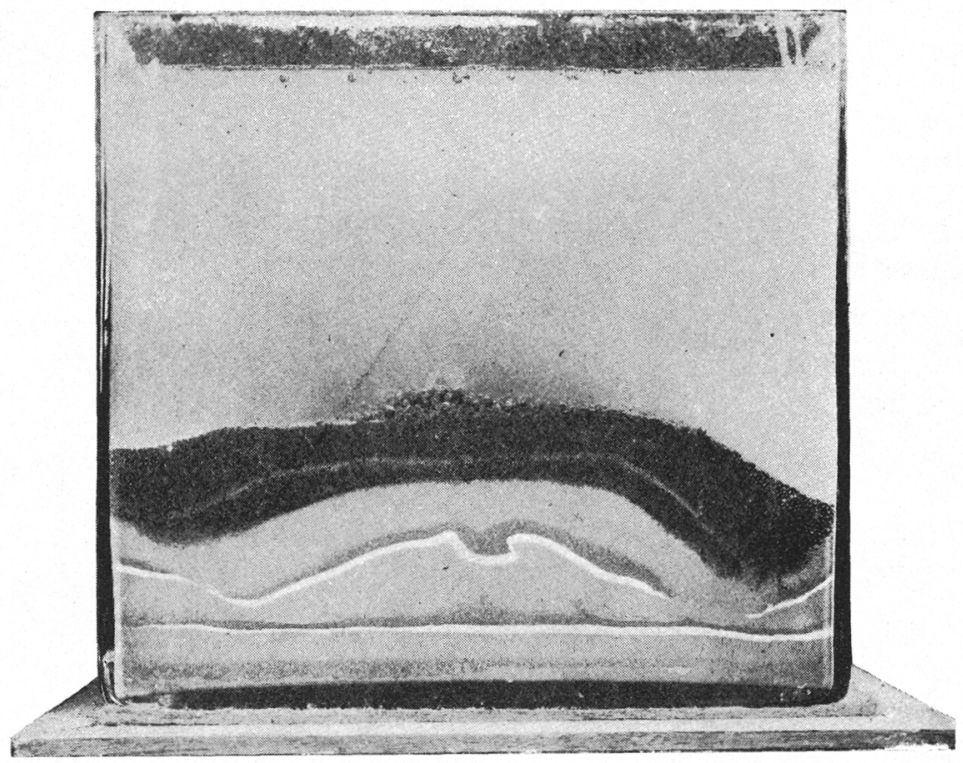

Figure 6.-Glass Tank Section composed of Clay, powdered Chalk, and Sand Strata originally horizontal

Weighting with shot has deformed the upper without disturbing the lower beds

flowage would be likely to assume would disturb in a more or less complex manner the bedding of soft laminated clay mud. Lenticular-shaped beds of soft mud inclosed by firmer beds, if in contact with a thick bed of superposed sand on one side, would under certain conditions give rise to such lateral flowage. One condition which would bring about such lateral migration of extra mobile layers would be current scour, as shown in these experiments, which would remove in one area the stronger superposed beds, causing the soft beds there to squeeze upward, as in figure 5, while elsewhere they flowed toward the base of the plug under pressure 
of the heavy sand beds. The experiment just described shows more or less disturbance of the entire thickness of the section.

Another experiment of a similar character to that already described shows that extensive disturbance and lateral movement may be produced in the higher beds of the experimental section with little or no effect on the beds immediately below. Shot was used for weighting the beds shown in figure 6, which represents the second experiment. The beds of clay, powdered chalk, and sand were horizontal at the beginning of the experiment. On one side of the tank in this experiment thrust-faulting was

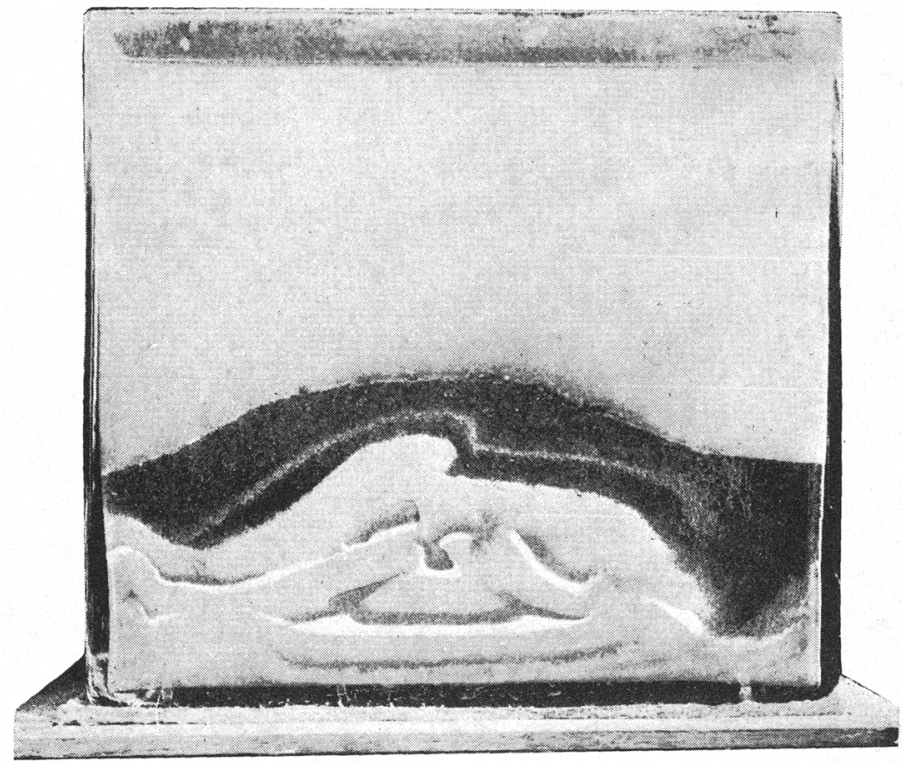

Figure 7.-Later stage in the Deformation shown in Figure 6

developed in the middle part of the section. In this photograph (figure 6) marked bending of the beds and crumpling of the upper beds is shown, with the lower beds entirely undisturbed. The next figure, number $\%$, shows a later stage of the same experiment. This experiment duplicates one of the conditions characteristic of the Ávon River beds, namely, disturbed beds resting on undisturbed beds. The other essential feature, horizontal beds above the contorted beds, would be supplied by the continuation of the normal processes of deposition laying down horizontal beds after the removal by current scour of the heavier and coarser beds which produced the deformation. 


\section{Explanation of 'the pistulibed Beds of Avon River}

The disturbed beils of the Avon River mud flats are believed to have originated through differential weighting of the beds acting in conjunetion with bottom scour which operated in the way suggested by the experiments to produce horizontal movement of the beds.

Disturbances of the bedding in strata of sand may originate in the same general way through the juxtaposition of beds of quicksand and ordinary sand. The extreme mobility of the former would be likely to cause readjustment of the layers if a leposit of ordinary heavy sand were

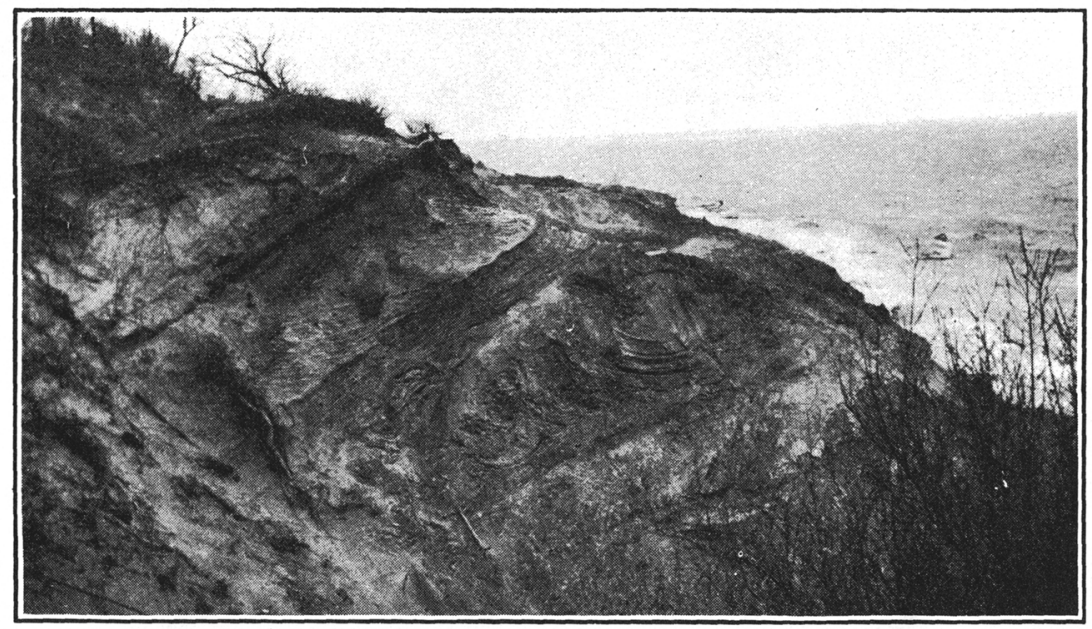

Figure 8.-Contorted Berls of Sand on Shore of Lake Erie west of Port Rowan, Onturio

laid in uneven thickness on it. Woodworth' has described a section at Port Kent, New York, in which the sands have been disrupted by clay, which has penetrated the sand after the manner of irregular dikes.

\section{The Chiffes of Porti Rowan, Ontario}

The cliffs of postglacial sands and clays which border the north shore of Lake Ontario 12 miles west of Port Rowan show a section in which a thickness of beds much greater than those described above have suffered deformation. These beds are composed chiefly of sand and are overlaid by horizontal and cross-bedded sands, as shown in figure 8 . They rest on lake clays which probably belong to the Lake Whittlesey stage of sedi-

${ }^{6}$ N, Y, State Mus. Bull, no, 84, 1905, p. 189, fig. 23 , 
mentation. 'The inclination of the beds toward the left is the result of a land slip which has dropped a seetion of the eliffs 10 to 75 yards wide and several hundred feet long into the waters of the lake. The bed showing disturbed strata has a thickness of 10 or 12 feet.

In seeking the cause of the highly inclined and disturbed condition of the strata, which at one point simulate the outline of a heart-shaped figure, the history of these beds should be considered. They were lairl down when Lake Erie was held at a level more than 100 feet higher than at present by the Lake Whittlesey ice-barrier. While the beds of this section were being assorted and shifted into their present position by wave and current action, large icelergs and extensive fields of floating ice were characteristic features of the surface of Lake Whittlesey, in which these beds were laid down. $\Lambda$ this stare of its history Lake Erie must have displayed in summer fields of floe-ice and icebergs quite comparable to those which today border the Greenland coasts in early summer. Any one who has seen an Arctic ice-pack moving majestically and with immeasurable force before the wind needs not to be told that an ice-pack when it grounds before a gale is capable of plowing up and disturbing in a very extensive fashion any unconsolidated beds on which it may be driven by the wind. Various observers have testified to the efficiency of grounded ice in disturbing bottom deposits on Arctic coasts. Quotations in this connection from two of these will suffice.

Lieut. Charles H. Stockton, of the United States Navy, thus descril)es the action of this ice when it is driven ashore:

"Sometimes a long line of heaty floe-ice from the pack grounds in the shallow water near the shore during northerly winds, pressed from behind by the force and the weight of the entire northern pack. It is gradually forced up, plowing its way through the bottom, at the same time rising gradually along the ascent of the bottom toward the land." ?

Lieutenant Stockton made a hydrographic survey of the anchorage near Point Barrow, in which he

"demonstrated that the contour of the bottom is constantly changed by the plowing and planing done by the heavy ice grounded and driven up by the pressure of the mighty ice-pack, under the influence of northerly winds and gales." s

The Lake Whittlesey ice-barrier which stretched along the north border of the lake but a short distance north of the section under consideration must have sent into the lake innumerable tongues of glacial ice, which

' Charles H. Stockton: Nat'l Geog. Mag., vol, i1, 1891, pp, 182, 183.

8 Ibid., p. 182 , 
334 E. M. KINDLE-DEFORMATION IN NOVA SCOTIA $\Lambda$ ND ONTARIO

before breaking up into bergs were unquestionably efficient agents in plowing up the bottom sands and clays and doubtless produced many examples of disturbed bedding comparable with that shown in figure 8 . The entire competence of ice, acting either as grounded fields or as tongues of glacial ice, to produce the disturbed bedding seen in the Lake Erie section west of Port Burwell, together with the great thickness and extent of the ice-fields which must have characterized the surface of Lake Erie during an early stage of its history, appear to justify the reference of this phenomenon to ice-action. 